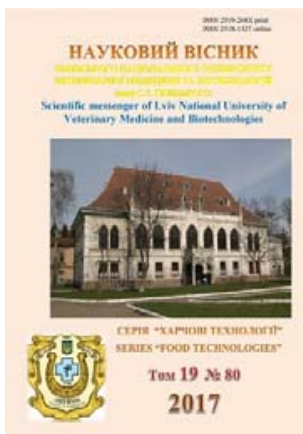

Науковий вісник Львівського національного університету ветеринарної медицини та біотехнологій імені С.3. Гжицького

Scientific Messenger of Lviv National University of Veterinary Medicine and Biotechnologies

doi:10.15421/nvlvet 8028

ISSN 2519-268X print

ISSN 2518-1327 online

http://nvlvet.com.ua/

УДК 664.699 (045)

\title{
Вплив інуліну з топінамбура на якість борошняних кулінарних виробів
}

\author{
В.В. Власенко, В.М. Криворук \\ 1skryv@gmail.com, vlasenkovanya@gmail.com \\ Вінницький торговельно-економічний інститут КНТЕУ, \\ вул. Соборна, 8, м. Вінниия, 721000, Украӥна
}

\begin{abstract}
Досліджено функиіонально-технологічні властивості впливу рідини на зміну реологічних характеристик тіста, оскільки оптимальне дозування води дозволяє отримати тісто з нормальною консистенцією, сухе на дотик, з доброю еластичністю і пружністю. Передозування рідини призводить до утворення липкого, розпливчатого тіста. При недостатньому введенні рідини отримують «туге» тісто. Борошняні кулінарні вироби з такого тіста отримують забиті, з поганою пористістю, низьким питомим об'ємом. Чим «сильніше» пшеничне борошно, тим більшу кількість води слід вводити в тісто для отримання борошняних кулінарних виробів з найбільшим об'ємом і кращою пористістю. Зі «слабким» борошном, навпаки, кількість води, що вводиться в тісто, слід знижувати, тому щчо тісто виходить липким, а це ускладнює його обробку. При иьому зменшення кількості води призводить до зниження виходу виробів і погіршення економічних показників виробництва.

Для встановлення оптимальних функціонально-технологічних властивостей були проведені дослідження впливу вологості тіста з інуліном на його реологічні властивості та якість борочняних кулінарних виробів. Консистенцію тіста при замімуванні змінювали за рахунок дозування води таким чином, щьоб крок ї̈ зміни до моменту готовності становив 50 о.ф. в діапазоні від 350 до 650 о.ф. Контрольним зразком використовували тісто з консистениією 640-650 о.ф. без інуліну. Тривалість замішування тіста визначали за першим піком на фаринограмі. Тривалість бродіння тіста визначали за максимальним значенням швидкості зміни кількості утвореного діоксиду вуглецю. В результаті дослідження було встановлено щьо при зниженні консистениії тіста з інуліном з 650 до 350 о. ф. вологість збільшується з 40,6 до 44,6\%, водопоглинальна здатність зростає з 54,7 до 66,8\% Кількість механічної енергї̈, витраченої на утворення структури тіста, знижується з 42,7 до 23,5 кДж/кг. Пластична деформація змінюється з 1,6 до 4,0 мм. Внаслідок иього змінилися фізико-хімічні показники борошняних кулінарних виробів з інуліном із топінамбура при консистенції тіста 450 і 500 о.ф., питомий об'єм знизився на 9\%, пористість на 2\%, загальна дерормація м'якушу на $10 \%$, крихкість на $2 \%$, технологічні витрати на упік і всихання на 2\% порівняно з контрольним зразком, щз дає можливість отримати вироби з підвищеною харчовою цінністю без погіршення органолептичних та фізико-хімічних показників готових виробів.

Ключові слова: інулін з топінамбура, водопоглинальна здатність, пластична деформація, фізико-хімічні показники, упік, всихання, борочняні кулінарні вироби.
\end{abstract}

\section{Влияние инулина из топинамбура на качество мучных кулинарных изделий}

\author{
В.В. Власенко, В.М. Криворук \\ lskryv@gmail.com, vlasenkovanya@gmail.com \\ Винницкий торгово-экономический институт КНТЭУ, \\ ул. Соборная 87, г. Винница, 21000, Украина
}

Исследованы функиионально-технологические свойства влияния жидкости на смену реологических характеристик теста, так как, оптимальная дозировка воды позволяет получить тесто с нормальной консистенцией, сухое на ошупь, с хорошей эластичностью и упругостью. Передозировка воды приводит к образованию липкого, расплывчатого теста. При

Citation:

Vlasenko, V., Krivoruk, V. (2017). Influence of inulin from topinambur quality of farm culinary products. Scientific Messenger LNUVMB, 19(80), $135-139$. 
недостаточном введении жидкости получают «тугое» тесто. Мучные кулинарные изделия из такого теста получаю забитье, с плохой пористостью, низким удельным обьемом. Чим «сильнее» пшеничная мука, тем большее количество водь следует вводить в тесто для получения мучных кулинарных изделий с наибольшим объемом и лучшей пористостью.

Для установления оптимальных функционально-технологических свойств были проведены исследования влияния влажности теста с инулином на его реологические свойства и качество мучных кулинарных изделий. Консистенцию теста при замесе меняли за счет дозирования воды, таким образом, чтобы шаг ее изменения до момента готовности составлял 50 о.ф. в диапазоне от 350 до 650 о.ф. Контрольным образиом использовали тесто с консистенцией 640-650 о.ф. без инулина. Продолжительность замеса теста определяли по первому пику на фаринограмме. Продолжительность брожения теста определяли по максимальному значению скорости изменения количества образованного диоксида углерода. В результате исследования было установлено, что при снижении консистенции теста с инулином с 650 до 350 о.ф. влажность увеличивается с 40,6 до 44,6\%, водопоглотительную способность возрастает с 54,7 до 66,8\%. Количество механической энергии, затраченной на образование структуры теста, снижается с 42,7 до 23,5 кДж / кг. Пластическая деформация изменяется с 1,6 до 4,0 мм. В результате изменились физико-химические показатели мучных кулинарных изделий с инулином из топинамбура при консистенции теста 450 и 500 о.ф., удельньй объем снизился на 9\%, пористость на 2\%, общая деформация мякоти на 10\%, хрупкость на 2\%, технологические затраты на упек и усыхание на 2\% по сравнению с контрольным образиом, что дает возможность получить изделия с повышенной пищевой ценностью без ухудшения органолептических и физико-химических показателей готовых изделий.

Ключевые слова: инулин из топинамбура, водопоглотительная способность, пластическая деформация, физикохимические показатели, упек, усыхание, мучные кулинарные изделия.

\title{
Influence of inulin from topinambur quality of farm culinary products
}

\author{
V. Vlasenko, V. Krivoruk \\ 1skryv@gmail.com, vlasenkovanya@gmail.com \\ Vinnitsa Trade and Economic institution \\ Soborna Str., 87, Vinnytsia, 21000, Ukraine
}

The functional and technological properties of the effect of liquid on the change of the rheological characteristics of the dough are investigated in this article, since the optimal dosage of water allows to obtain the dough from a normal consistency, dry to the touch, with good elasticity and elasticity. Overdosing of water leads to the formation of a sticky, diffuse dough. If the liquid is not injected, a «tight» dough is obtained. Flour culinary products from such a dough get bruises, with poor porosity, low specific volume. The "stronger» wheat flour, the more water should be introduced into the dough to produce borshchannel culinary products with the largest volume and better porosity. With «weak» flour, on the contrary, the amount of water introduced into the dough should be reduced, because the dough turns out to be sticky, and this makes it difficult to process. At the same time, a decrease in the amount of water leads to a decrease in the yield of products and a deterioration in the economic performance of production.

To determine the optimum functional and technological properties, studies were made of the effect of dough moisture with inulin on its rheological properties and the quality of flour culinary products. The consistency of the dough during the mixing was changed by dosing the water, so that the step of changing it until it was ready was $50 \mathrm{o}$. ph. in the range from 350 to $650 \mathrm{o}$. $f$. The control sample was a dough with a consistency of 640-650 o. f. without inulin.

The duration of the kneading test was determined by the first peak on the pharynograms. The duration of the fermentation of the test was determined from the maximum value of the rate of change in the amount of carbon dioxide formed. The result of the study found that with a reduction in the consistency of the dough with inulin from 650 to 350 o. $f$. humidity increases from 40.6 to $44.6 \%$, water-clogging capacity increases from 54.7 to $66.8 \%$. The amount of mechanical energy spent on the formation of the test structure decreases from 42.7 to $23.5 \mathrm{~kJ} / \mathrm{kg}$. Plastic deformation varies from 1.6 to $4.0 \mathrm{~mm}$. As a result, the physicochemical parameters of flour culinary products from inulin Jerusalem artichoke at the consistency of the test 450 and 500 o. ph. Specific volume decreased by $9 \%$, porosity by $2 \%$, total deformation of the pulp by $10 \%$, brittleness by $2 \%$, technological costs for baking and drying by $2 \%$ compared to the control sample, which makes it possible to obtain products with increased nutritional value, without deterioration organoleptic and physico-chemical indicators of finished products.

Key words: inulin from topinambur, water absorbing ability, plastic deformation, physicochemical indices, dip, drying, flour culinary products.

\section{Вступ}

При оцінці якості борошняних кулінарних виробів споживач звертає особливу увагу на показники текстури. Отримання готових виробів із заданими показниками текстури може бути забезпечено тільки за рахунок керування реологічними властивостями напівфабрикатів з урахуванням пекарських властивостей сировини і рецептури виробів (Auerman, 2014).

Кількість води, що вноситься в тісто при замішуванні, залежить від ряду факторів: виду виробів, сорту (виходу) борошна, його «сили», способу приготування тіста, активності власних ферментів боро- шна, кількості та виду внесених добавок та інших чинників (Drobot, 2012).

Оптимальне дозування води дозволяє отримати тісто з нормальною консистенцією, сухе на дотик, 3 доброю еластичністю і пружністю. Передозування води призводить до утворення липкого, розпливчатого тіста. При недостатньому введенні води отримують «туге» тісто. Борошняно-кулінарні вироби 3 такого тіста виходять забиті, з поганою пористістю, низьким питомим об'ємом (Peresichnyi et al., 2013).

Чим «сильніше» пшеничне борошно, тим більшу кількість води слід вводити в тісто для отримання борошняноно-кулінарних виробів 3 найбільшим 
об'ємом і кращою пористістю. Зі «слабким» борошном, навпаки, кількість води, що вводиться в тісто, слід знижувати, тому що тісто виходить липким, а це ускладнює його обробку. При цьому зменшення кількості води призводить до зниження виходу виробів і погіршення економічних показників виробництва.Чим більше в тісті рідини, тим інтенсивніше протікають процеси набухання і пептизаціі білків i тим швидше відбувається його розрідження. При збільшенні кількості води в тісті збільшується швидкість ферментативних реакцій (Puchkova et al., 2005).

Аналіз останніх досліджень і публікацій. Створенню технологій борошняних виробів функціонального призначення присвячені роботи вчених: А.Д. Грищенко, В.І. Дробот, Л.А.Міхонік, Г.М. Лисюк, О.В. Самохвалова, М.Ф. Кравченко, М.I. Пересічного (Puchkova et al., 2005; Peresichnyi et al., 2013; Medved and Kozak, 2014). Незважаючи на значну кількість праць, питання функціональної спрямованості борошняних виробів $є$ недостатньо опрацьованими.

Мета роботи дослідити вплив інуліну з топінамбура на технологічні, фізико-хімічні показники, 3 одержанням готових борошняних кулінарних виробів з найкращими споживчими показниками якості.

\section{Матеріал і методи дослідження}

Дослідження проводилися в лабораторії підприємства Вінницького підрозділу «Вінницяхліб» ПАТ «Концерн Хлібпром» де визначалась раціональна

консистенція тіста, яка забезпечувала отримання готових виробів з найкращими споживчими показниками якості та дозволяла надалі визначати водопоглинальну здатність перероблюваних партій борошна для даного виду виробів, з гелеутворюючою здатністю. Нами були проведені дослідження впливу вологості тіста 3 інуліном на його реологічні властивості та якість борошняних кулінарних виробів. Консистенцію тіста при замішуванні змінювали за рахунок дозування води, таким чином, щоб крок іiі зміни до моменту готовності становив 50 o. $\phi$. в діапазоні від 350 до 650 о. $\phi$. Контрольним зразком було тісто 3 консистенцією 640-650 о.ф. без інуліну.

Тривалість замішування тіста визначали за першим піком на фаринограмі. Тривалість бродіння тіста визначали за максимальним значенням швидкості зміни кількості утвореного діоксиду вуглецю.

\section{Результати та їх обговорення}

Показники якості борошняних кулінарних виробів iз пшеничного борошна 3 досліджуваними добавками залежно від консистенції подано в таблицях 1, 2, 3 та рис. 1 А і Б.

Як видно 3 таблиці 1 консистенція пшеничного тіста 3 інуліном змінилася 3650 до 350 o. $ф$. тобто вологість збільшувалася з 40,6 до 44,6\%, водопоглинальна здатність зростала 3 54,7 до $66,8 \%$.

Таблиичя 1

Зміна параметрів замішування тіста 3 інуліном залежно від його вологості та з урахуванням консистенції

\begin{tabular}{|l|c|c|c|c|c|c|c|c|}
\hline \multirow{2}{*}{$\begin{array}{c}\text { Найменування } \\
\text { параметрів }\end{array}$} & \multicolumn{7}{|c|}{ Параметри залежно від консистенії тіста } \\
\cline { 2 - 11 } & $\mathrm{K}$ & 650 & 600 & 550 & 500 & 450 & 400 & 350 \\
\hline Кількість води на замішування, & 172 & 164 & 170 & 176 & 182 & 188 & 194 & 200 \\
\hline Вологість тіста, \% & 42,8 & 40,6 & 40,2 & 42,0 & 42,6 & 42,8 & 43,0 & 44,6 \\
\hline ВП3, \% & 57,3 & 54,7 & 56,8 & 58,8 & 60,8 & 62,8 & 64,8 & 66,8 \\
\hline Тривалість замішування, с & 100 & 125 & 125 & 120 & 110 & 110 & 100 & 100 \\
\hline
\end{tabular}

Вплив консистенції тіста з інуліном на його реологічні властивості

Таблиця 2

\begin{tabular}{|c|c|c|c|c|c|c|c|c|}
\hline \multirow{2}{*}{$\begin{array}{c}\text { Найменування } \\
\text { параметрів }\end{array}$} & \multicolumn{8}{|c|}{ Параметри в залежності від консистенції тіста } \\
\hline & K & 650 & 600 & 550 & 500 & 450 & 400 & 350 \\
\hline $\mathrm{h}_{\text {заг, }}, \mathrm{MM}$ & 5,6 & 2,8 & 3,4 & 3,5 & 3,8 & 3,7 & 4,2 & 5,5 \\
\hline $\mathrm{h}_{\text {пласт }}, \mathrm{MM}$ & 4,0 & 1,6 & 1,9 & 2,0 & 2,3 & 2,0 & 3,0 & 4,0 \\
\hline $\mathrm{h}_{\text {пруж},}, \mathrm{MM}$ & 1,6 & 1,2 & 1,5 & 1,5 & 1,5 & 1,7 & 1,2 & 1,5 \\
\hline$\Delta \mathrm{h}$ & 0,71 & 0,57 & 0,56 & 0,57 & 0,60 & 0,54 & 0,71 & 0,73 \\
\hline Адгезійна напруга після замішування, кПа & 8,2 & 4,6 & 4,3 & 2,7 & 3,4 & 4,4 & 2,1 & 2,2 \\
\hline Адгезійна напруга після дозрівання, кПа & 3,2 & 2,3 & 3,6 & 4,2 & зд & 5,6 & 3,5 & 3,0 \\
\hline $\begin{array}{l}\text { Кількість механічної енергії, витраченої на } \\
\text { формування структури тіста, Ауд, кДж/кг }\end{array}$ & 42,8 & 42,7 & 41,1 & 37,4 & 34,5 & 30,7 & 26,4 & 23,5 \\
\hline
\end{tabular}

Результати дослідження таблиці 2 показують, що кількість механічної енергії, витраченої на утворення структури тіста, знижувалася з 42,7 до 23,5 кДж/кг, а пластична деформація змінювалася 3 1,6 до 4,0 мм На (рис. 1 А). показано зміни консистенції тіста 3 інуліном, а на (рис. 2 Б) показана динаміка деформаційних характеристик.

Результати досліджень змін фізико-хімічних показників борошняних кулінарних виробів 3 інуліном із топінамбура показано у табл. 3, та на рис. 2 . 


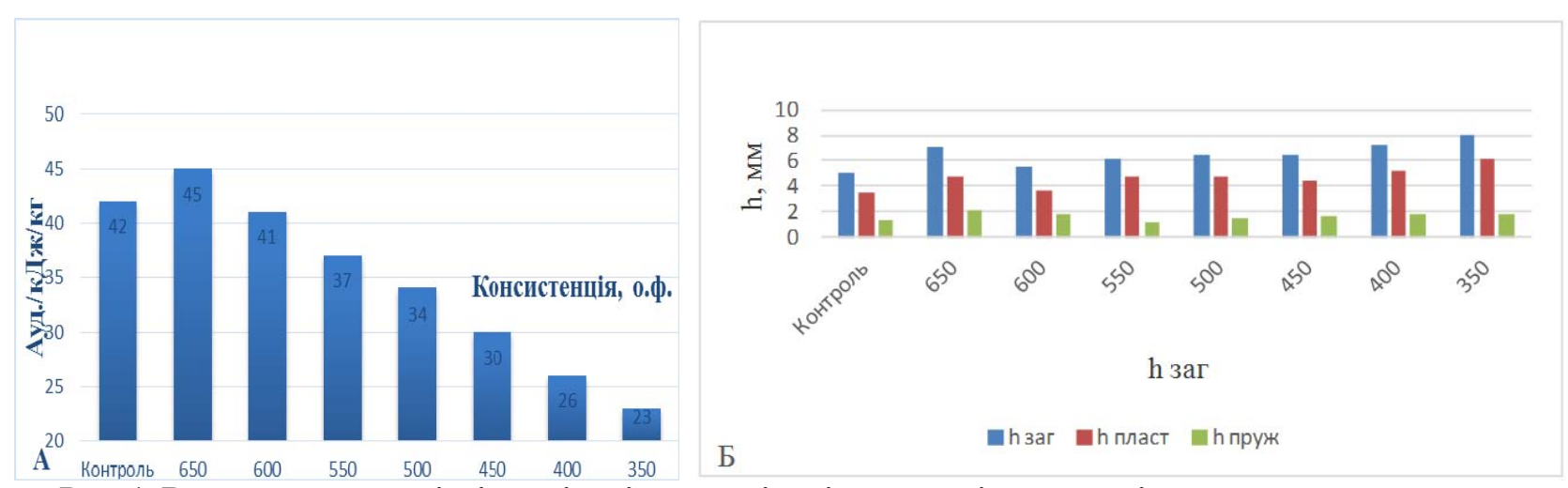

Рис. 1. Вплив консистенції тіста з інуліном на кількість механічної енергії, витраченої на утворення структури тіста (А) і деформаційні характеристики (Б)

Вплив консистенції пшеничного тіста з інуліном на фізико-хімічні показники

Таблиияя 3 борошняних кулінарних виробів

\begin{tabular}{|c|c|c|c|c|c|c|c|c|}
\hline \multirow{2}{*}{$\begin{array}{c}\text { Найменування } \\
\text { показників }\end{array}$} & \multicolumn{8}{|c|}{ Показники залежно від консистенції тіста } \\
\hline & K & 650 & 600 & 550 & 500 & 450 & 400 & 350 \\
\hline \multicolumn{9}{|c|}{ Показники якості } \\
\hline Вологість, \% & 42,0 & 40,0 & 39,9 & 41,5 & 41,9 & 42,0 & 42,0 & 43,0 \\
\hline Кислотність, град & 1,5 & 1,6 & 1,4 & 1,4 & 1,5 & 1,5 & 1,6 & 1,6 \\
\hline Питомий об'єм, $\mathrm{cm}^{3} / \Gamma$ & 4,5 & 3,7 & 3,8 & 4,0 & 4,2 & 4,1 & 3,8 & 3,8 \\
\hline Пористість, \% & 83 & 78 & 78 & 79 & 81 & 81 & 78 & 76 \\
\hline Крихкість, \% & 9,2 & 6,2 & 6,5 & 7,5 & 7,6 & 7,8 & 9,5 & 10,5 \\
\hline $\mathrm{h}_{3 \mathrm{ar}}, \mathrm{MM}$ & 5,6 & 3,9 & 5,3 & 6,3 & 5,0 & 6,9 & 5,9 & 5,8 \\
\hline $\mathrm{h}_{\text {пласт }}, \mathrm{MM}$ & 2,5 & 1,7 & 2,4 & 2,5 & 2,3 & 2,8 & 2,4 & 2,5 \\
\hline $\mathrm{h}_{\text {пруж}}, \mathrm{MM}$ & 3,1 & 2,2 & 2,9 & 3,8 & 2,7 & 4,1 & 3,5 & 3,3 \\
\hline$\Delta \mathrm{h}$ & 0,45 & 0,44 & 0,45 & 0,40 & 0,46 & 0,40 & 0,41 & 0,43 \\
\hline \multicolumn{9}{|c|}{ Технологічні втрати } \\
\hline Упік,\% & 8,0 & 6,9 & 6,6 & 7,5 & 6,9 & 7,1 & 6,8 & 6,6 \\
\hline Всихання, \% & 4,5 & 3,8 & 3,8 & 3,4 & 3,5 & 3,8 & 4,2 & 4,2 \\
\hline$\sum_{\text {aтрат }}^{\text {гекн, }}$ & 12,5 & 10,6 & 10,4 & 10,8 & 10,3 & 10,9 & 10,9 & 10,8 \\
\hline
\end{tabular}

Як видно з результатів дослідження (табл. 3), спостерігаються зміни фізико-хімічних показників борошняних кулінарних виробів з інуліном із топінамбура при консистенції тіста 450 і 500 o. ф.

В процесі дослідження питомий об'єм знижувався на 9\%, пористість на 2\%, загальна деформація м'якушу на $10 \%$, крихкість на $2 \%$, технологічні витрати на упік і всихання на 2\% порівняно з контрольним зразком (рис. 2 А і Б).
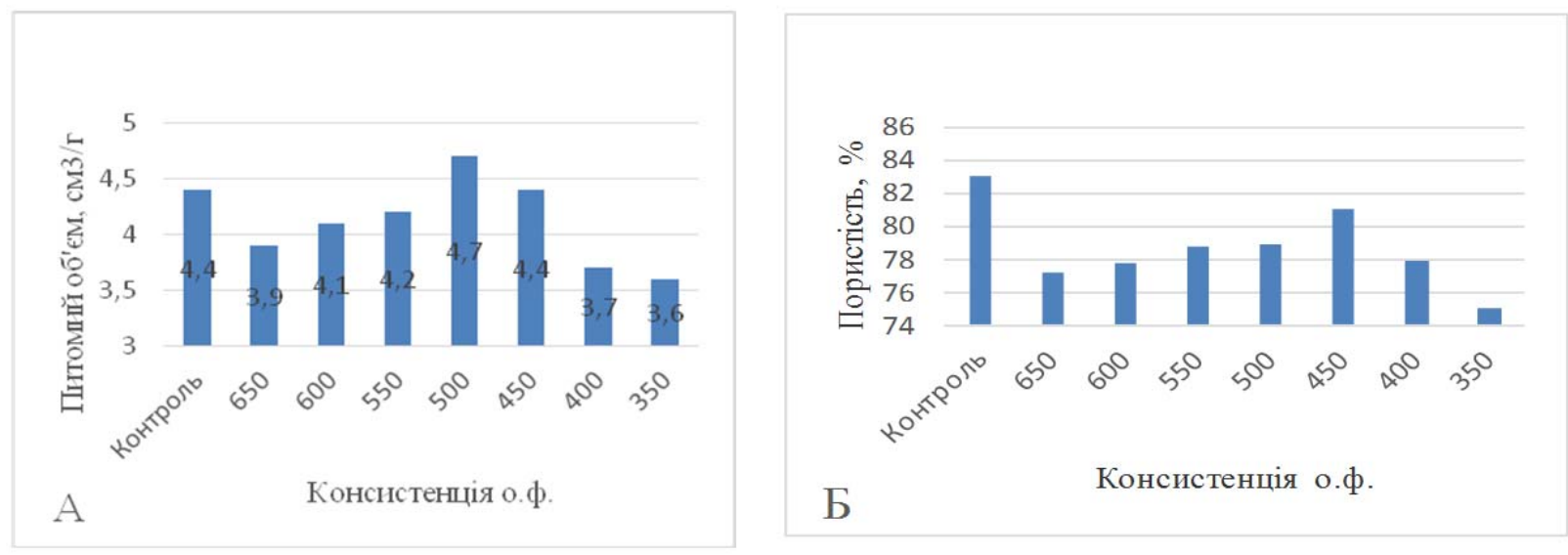

Рис. 2. Вплив консистенції пшеничного тіста з інуліном із топінамбура на питомий об'єм (А) і пористість (Б) борошняних кулінарних виробів 
Аналіз отриманих експериментальних даних показав, що якість борошняних кулінарних виробів, виготовлених $з$ використанням інуліну, за показником питомого об'єму поступилася в середньому на 10\%. При цьому встановлено, що консистенція тіста, яка дозволяє отримати борошняно-кулінарні вироби найкращої якості, перебуває в діапазоні $480 \pm$ 20 o. $\phi$.

Використання інуліну при випіканні борошняних кулінарних виробів сприяло зниженню технологічних витрат на упік та всихання в середньому на 2\% порівняно з контрольною зразком, що пов'язано зі здатністю інуліну зв'язувати вологу.

Таким чином, на підставі проведених досліджень була визначена консистенція пшеничного тіста 3 внесенням інуліну з топінамбура (дозування 9\%), що дорівнює $480 \pm 20$ о. ф., яка дозволяє отримати борошняні кулінарні вироби з показниками якості, що відрізняються від контрольного зразка.

\section{Висновки}

Отримані дані свідчать про те, що при виробництві борошняних кулінарних виробів, збагачених інуліном із топінамбура, необхідно застосовувати певні технологічні прийоми, при яких можна отримати вироби 3 підвищеною харчовою цінністю без погіршення орга- нолептичних та фізико-хімічних показників готових виробів.

\section{Бібліографічні посилання}

Auerman, L.Ja. (2014). Tehnologija hlebopekarnogo proizvodstva: uchebnik - 9-e izd. pererab. i dop. Professija (in Russian).

Drobot, V.I. (2012). Dovidnyk z tekhnolohii khlibopekarskoho vyrobnytstva. K.: Ruslana (in Ukrainian).

Peresichnyi, M.I., Kravchenko, M.F., Fedorova, D.V. (2013). Tekhnolohiia produktiv kharchuvannia funktsionalnoho pryznachennia: monohrafiia. K.: KNTEU (in Ukrainian).

Puchkova, L.I., Polandova, R.D., Matveeva, I.G. (2005). Tehnologija hleba konditerskih i makaronnyh izdelij. Tehnologija hleba. SPb: GIORD (in Russian).

Medved, L.M., Kozak, V.M. (2014). Tekhnolohiia boroshnianykh kondyterskykh vyrobiv. Poltava: PUET (in Ukrainian).

Received 16.09.2017

Received in revised form 20.10.2017

Accepted 25.10.2017 